\title{
A new species of Amazophrynella (Anura: Bufonidae) from southern Amazonia
}

\author{
ROBSON W. ÁVILA ${ }^{1}$, VINICIUS T. CARVALHO ${ }^{2,3}$, MARCELO GORDO $^{4}$, \\ RICARDO A. KAWASHITA-RIBEIRO ${ }^{5} \&$ DRAUSIO H. MORAIS ${ }^{6}$ \\ ${ }^{1 .}$ Universidade Regional do Cariri, Centro de Ciências Biológicas e da Saúde, Departamento de Ciências Biológicas, Campus do \\ Pimenta, Rua Cel. Antonio Luiz, 1161, Bairro do Pimenta, 63105-100, Crato, CE, Brazil. \\ Corresponding author: robsonavila@gmail.com \\ 2. Universidade Federal do Amazonas-UFAM, ICB, Programa de Pós-graduação em Biodiversidade e Biotecnologia, Av. Gen. \\ Rodrigo Octávio Jordão Ramos, 3000, Setor Sul, Bloco M, CEP 69077-000, Manaus, Amazonas, Brazil. \\ ${ }^{3}$ Instituto Nacional de Pesquisas da Amazônia, Coleção de Anfíbios e Répteis, Campus II, Av. André Araújo, 2936, Aleixo, CEP \\ 69060-000, Manaus, AM, Brazil. \\ 4. Departamento de Biologia, ICB, Universidade Federal do Amazonas, Av Gen. Rodrigo Octávio Jordão Ramos, 3000, Manaus, AM, \\ Brasil.CEP69077-000.projetosauim@gmail.com \\ 5. Programa de Pós-Graduação em Ecologia e Conservação da Biodiversidade, Instituto de Biociências, Universidade Federal de \\ Mato Grosso, Av. Fernando Corrêa da Costa, 2367, CEP 78060-900, Cuiabá, MT, Brazil. \\ 6. UNESP_Univ. Estadual Paulista, Campus de Botucatu, Instituto de Biociencias, Departamento de Parasitologia, Botucatu, Sao \\ Paulo, Brazil.
}

\begin{abstract}
A new species of the genus Amazophrynella is described from southern Amazonia, Brazil. The new species is characterized by its medium size for the genus (15.2-19.3 mm SVL in males, 20.2-25.7 mm SVL in females), snout rounded in dorsal view, acute in lateral view, presence of subrostral crest not converging anteriorly, finger I shorter than finger II, and by dorsal and ventral coloration. The reproductive behavior of the new species is similar to other Amazophrynella with pigmented and numerous eggs that are probably laid in temporary ponds.
\end{abstract}

Key Words: Amphibia, Bufonidae, Anura, Amazon

\section{Introduction}

The formerly known Neotropical genus Dendrophryniscus Jiménez de la Espada, 1871, was until recently consisted of ten small species distributed in Amazonia and the Atlantic forest in Colombia, Ecuador, Peru, Guiana and Brazil (Frost, 2011). Recently, the systematic of Dendrophryniscus was studied by Fouquet et al. (2012a, b) based on both molecular and morphological data and they erected the genus Amazophrynella to accommodate the Amazonian species. Thus, eigth species of Dendrophryniscus were recognized, all of them inhabiting the Atlantic Forest domain in southeastern and southern region of Brazil (D. berthalutzae Izecksohn, 1994, D. brevipollivatus Jiménez de la Espada, 1871, D. carvalhoi Izecksohn, 1994, D. leucomystax Izecksohn, 1968, D. oreites Recoder, Teixeira Jr, Cassimiro, Camacho and Rodrigues, 2010, D. organensis Carvalho-e-Silva, Mongin, Izeckson, and Carvalho-e-Silva, 2010, D. proboscideus (Boulenger, 1882) and D. stawiarskyi Izecksohn, 1994). In Amazonia, two species of Amazophrynella were therefore recognized (A. bokermanni Izecksohn, 1993, and A. minuta Melin, 1941).

Herein, we describe a new species of Amazophrynella that inhabits Amazonian forests south of the Amazon River in the states of Mato Grosso, Rondônia and Amazonas, Brazil.

\section{Material and Methods}

Specimens examined and used for comparisons are deposited at the Coleção Zoológica de Vertebrados da 